\title{
НОВІ ПІДХОДИ ДО КОРЕКЦІЇ ПОСТАВИ У ЛЮДЕЙ МОЛОДОГО ВІКУ
}

\author{
Є. Ю. Телиця, Г. О. Стельмах, Т. Г. Бакалюк \\ Тернопільський національний медичний університет \\ імені І. Я. Горбачевського МОЗ Украӥни
}

Стаття присвячена дослідженню ефективності реабілітаційних методик для корекції синдрому крилоподібних лопаток у людей молодого віку з порушенням постави. Отримані дані показують, що включення методу постізометричної релаксації в реабілітаційний комплекс більше сприяє відновленню постави та збільшенню сили м’язів, які беруть участь у рухах лопатки.

\section{NEW APPROACHES TO POSTURE CORRECTION IN YOUNG PEOPLE}

\author{
Ye. Yu. Telytsya, H. O. Stelmakh, T. H. Bakaliuk

\section{Horbachevsky Ternopil National Medical University}

The article is devoted to the study of the effectiveness of rehabilitation methods for the correction of the wingshaped shoulder blade syndrome in young people with postural disorders. The data obtained show that the inclusion of the postisometric relaxation method in the rehabilitation complex more contributes to restoring the posture and increasing the strength of the muscles involved in the scapula movements.

Вступ. Масовий характер порушень постави і викривлень хребта - одна з найбільш злободенних проблем сучасного суспільства. Від того, в якому стані перебуває хребет, м'язи, які його оточують, та зв'язки, залежить постава людини. Патологічні процеси, які викликають зміни в збільшенні або зменшенні природних вигинів хребта, і його бокові деформації, які були діагностовані ще в ранньому дитинстві, в період статевого дозрівання будуть прогресувати набагато швидше. Найвища ступінь прогресування захворювання припадає на закінчення росту організму, коли опорно-руховий апарат стає повністю сформований $[2,3]$.

У зв'язку з тим, що з кожним роком вимоги до якості вищої освіти зростають, навчальна діяльність студентів передбачає проведення більшої частини часу сидячи, що рефлекторно тягне за собою дисфункцію м'язів, які утримують хребет. Як наслідок, виникає порушення постави. Саме тому, питання діагностики і корекції порушень постави у студентства з кожним роком набуває все більшого значення $[3,7]$.

Одним із проявів порушення постави $\epsilon$ синдром крилоподібних лопаток, який виникає через слабкість привідних м'язів, які зближують лопатки, - трапецієподібного та ромбоподібного [1]. При зниженні тонусу переднього зубчастого м'яза лопатка також буде займати аномальне положення. Синдром крилоподібних лопаток може виникнути у людей молодого віку внаслідок травм, розтягнення м'язів, вивиху суглобів плеча, порушення постави, неправильного розподілу навантаження, слабкості м'язового корсета, гіподинамії та ін. [2].

Корекція порушень постави передбачає включення різних засобів фізичної реабілітації $[2,5,6]$. Однак у багатьох поширених методиках відновлення постави не враховують роль дисбалансу ключових м'язів, що запускають патогенетичні механізми і спричиняють прогресування порушень статики і довільних рухів $[4,6]$.

Незважаючи на те, що існує велика кількість методик фізичної терапії для корекції постави, відсутні дослідження про вивчення впливу методів фізичної реабілітації на відновлення м'язів, що і зумовило тему нашого дослідження.

Мета дослідження: дослідити ефективність реабілітаційних методик для корекції синдрому крило-

(c) Є. Ю. Телиця, Г. О. Стельмах, Т. Г. Бакалюк, 2020 
подібних лопаток у людей молодого віку з порушенням постави.

Основна частина. У дослідженні брали участь 22 особи віком 17-22 роки, середній вік становив $(19,7 \pm 0,9)$ року, в яких виявлено порушення постави та синдром крилоподібних лопаток.

Згідно з проведеним анкетуванням, факторами ризику, які мали негативний вплив на зміну постави у студентів, були: недостатній руховий режим (64\%), низький рівень фізичного стану (37\%), неправильне фізичне виховання (41\%), порушення гігієнічних умов режиму навчання і праці (32 \%), низька мотивація на формування правильної постави (21\%).

Усім обстежуваним проведено візуально-пальпаторне обстеження. Методом рандомізації створено дві групи (в I групу входило 10 осіб, в ІІ групу - 12). Реабілітаційний комплекс, який був застосований в обох групах, складався з комплексу лікувальної гімнастики для постави, який виконували 3 рази на тиждень протягом 3-х тижнів, та масажу м'язів спини № 10. Різниця між групами полягала в тому, що в II групі додатково до запропонованого реабілітаційного комплексу застосовували вправи постізометричної релаксації (ПІР) для переднього зубчастого м'яза, ромбоподібних, підлопаткових та трапецієподібних м'язів. Для проведення ПІР ми докладно пояснювали пацієнтам, які відчуття вони будуть мати. Вправи ПІР проводили за рекомендаціями К. Левіта [8].

Дослідження проводили в три етапи: перший до початку застосування реабілітаційних заходів, другий - на 10-й день, третій - після проведення реабілітації.

Критеріями ефективності реабілітаційних комплексів були дані візуальної діагностики, сколіометрії, тест Адамса, проба Отта, визначення дихальної екскурсії грудної клітки та мануальне м'язове тестування (ММТ) ромбоподібних, підлопаткових та трапецієподібних м'язів.

Аналіз результатів візуально-пальпаторного обстеження дозволив виявити на початку дослідження, що 100 \% пацієнтів мають рефлекторний постуральний дисбаланс м'язів у плечолопаткових ділянках, тонусно-силовий дисбаланс м'язів зафіксовано у $87 \%$ студентів, які взяли участь в дослідженні.

На 10-й день застосування реабілітаційних заходів, за даними анкетування, пацієнти обох груп відзначали поліпшення самопочуття. При їх обстеженні виявлено, що в II групі більш значимо відзначали зниження напруження м'язів плечового поясу, збільшення сили в ромбоподібних, підлопаткових та трапецієподібних м'язах.

Після проведення реабілітаційних заходів у пацієнтів II групи виявлено суттєве поліпшення постави та зменшення синдрому крилоподібних лопаток: зменшилась вираженість асиметрії тулуба та дисбалансу м'язів, покращились функціональні рухи у хребті, нормалізувався м'язовий тонус у трапецієподібних м'язах та, за даними ММТ, повністю відновилась сила в ромбоподібних, підлопаткових та трапецієподібних м'язах.

Після трьохтижневого курсу реабілітації, в I групі позитивного результату досягнуто у 36 \% пацієнтів, у II групі - в $87 \%$.

Отже, при наявності синдрому крилоподібних лопаток у осіб із порушенням постави доцільно проводити візуальну діагностику та ММТ для виявлення м'язової дисфункції, яка потребує корекції.

Проведені дослідження $\epsilon$ основою для створення реабілітаційних програм, що включають біомеханічну корекцію хребта та індивідуальні комплекси лікувальної фізкультури. Розробка диференційованих реабілітаційних програм і підтвердження їх ефективності $\epsilon$ метою подальших досліджень в цьому напрямку.

Висновки. За результатами дослідження встановлено, що при наявності синдрому крилоподібних лопаток для корекції порушень постави доцільно ввести до реабілітаційного комплексу вправи постізометричної релаксації для ромбоподібних, підлопаткових та трапецієподібних м'язів.

\section{СПИСОК ЛІТЕРАТУРИ}

1. Гаджиев С. А. Мышечные заболевания / С. А. Гаджиев, Л. В. Догель. - М. : «Медицина», 2014. - 324 с.

2. Епифанов В. А. Реабилитация в травматологии / В. А. Епифанов, А. В. Епифанов. - М. : ГЭОтАР-Медиа, 2010. - 331 c.

3. Красикова И. Осанка. Воспитание правильной осанки. Лечение нарушений осанки / И. Красикова. - М. : Издательство «Корона-Век», 2013. - 176 с.

4. Профілактор Євмінова як засіб корекції порушень постави у школярів : навч. посіб. / П. Д. Плахтій, В. М. Му- 
хін, В. В. Євмінов, І. О. Куделя. - Кам'янець-Подільський : [Абетка], 2006. - 159 с.

5. The effectiveness of scoliosis screening programs: Methods for systematic review and expert panel recommendations formulation / M. Beausejour, L. Goulet, S. Parent [et al.] // Scoliosis. - 2013. - No. 8. - P. 12.
6. Congenital Scoliosis: an up-to-date / G. Burnei, S. Gavriliu, C. Vlad [et al.] // J. Med. Life. - 2015. - Vol. 8 (3). - P. 388-397.

7. Complications associated with surgical repair of syndromic scoliosis / B. J. Levy, J. F. Schulz, E. D. Fornari, A. L. Wollowick // Scoliosis. - 2015. - No. 10. - P. 14.

8. Lewit K. Manualle medizin / K. Lewit. - Leipzig, 1987. -345 S.

Отримано 22.01.20 